\title{
Acute ethanol dosage reduces the synthesis of smooth muscle contractile proteins in the small intestine of the rat
}

\author{
V R PREEDY, P DUANE, AND T J PETERS \\ From the Division of Clinical Cell Biology, MRC Clinical Research Centre, Harrow, Middlesex
}

SUMMARY The effects of an acute dose of ethanol $(75 \mathrm{mmol} / \mathrm{kg}$ body weight; ip) on protein synthesis were investigated in the small intestine of the rat $(n=6)$. Control rats $(n=6)$ were injected with isovolumetric $0.15 \mathrm{~mol} / \mathrm{l} \mathrm{NaCl}$, ip. After $2.5 \mathrm{~h}$, fractional rates of protein synthesis (defined as the percentage of tissue protein renewed each day by synthesis and RNA efficiencies (defined as the amount of protein synthesised per unit RNA) were measured with a large flooding dose $(0 \cdot 3 \mathrm{Ci} / \mathrm{mol}$; $150 \mathrm{mmol} / \mathrm{l} ; 150 \mu \mathrm{mol} / 100 \mathrm{~g}$ body weight; iv) of $\left[4^{3} \mathrm{H}\right]$-phenylalanine. Rats were killed $10 \mathrm{minutes}$ after injection of the isotope and portions of the small intestine were rapidly dissected and frozen. Tissues and plasma were processed for phenylalanine specific radioactivities to obtain fractional rates of protein synthesis or protein synthesis rates relative to RNA. Rates of protein synthesis in mixed tissue proteins fell approximately $15-25 \%$ ( $p$ ranged from $<0.005$ to $>0.05$ ), in response to acute ethanol dosage. The decrease in the synthesis rates of the cytoplasmic protein fraction was similar $(\mathbf{p}<0.025)$. Proteins extracted from the smooth muscle contractile apparatus, however, showed a greater response to ethanol - that is, $40-50 \%$ inhibition in protein synthesis $(p<0.001)$. It is therefore possible that the functional disturbances in the ethanol-exposed gut may be because of changes in smooth muscle protein turnover with decreased amounts of contractile apparatus.

Approximately one third of patients being treated for chronic alcohol abuse have symptoms of gastrointestinal disturbances.' Diarrhoea is a frequent manifestation of alcohol abuse and may be accompanied by malabsorption. ${ }^{23}$ The basis of these metabolic disturbances is unknown. Studies in the laboratory rat have shown that acute ethanol exposure causes morphological changes in the small intestine, including haemorrhagic erosions of jejunal villi and enterocyte loss from villus tips, ${ }^{4}$ associated with changes in permeability. ${ }^{5}$ However, the effects of ethanol on the smooth muscle contractile apparatus have received very little attention. Robels et al have shown in man an inhibition of type I (forward progress) and type III (propulsion) waves. ${ }^{6}$

Address for correspondence: Dr V R Preedy, Division of Clinical Cell Biology, MRC Clinical Research Centre, Watford Road, Harrow, Middx HA1 3UJ

Received for publication 25 April 1988
Decreases in the frequency and amplitude of basal motility waves in the human rectosigmoid and disruption of canine myoelectric complexes ${ }^{78}$ have also been observed in response to acute ethanol. It is possible that defects in the rate of smooth muscle protein turnover may be responsible for these functional disturbances in intestinal motility. In this study the possibility that acute ethanol exposure decreases protein synthesis in the small intestine and that different tissue components respond differently was examined.

\section{Methods}

ANIMALS $\mathrm{L}\left[4^{3} \mathrm{H}\right]$-Phenylalanine was from Amersham International (Amersham, UK), and all other reagents were obtained from Sigma Chemical Company Ltd (Poole, Dorset, UK). Male rats, Wistar strain, were 
obtained from the National Institute for Medical Research (Mill Hill, London) at weaning, housed in a temperature controlled environment on a 12 hour light/dark cycle and fed a commercial pelleted diet ad lib until $95-105 \mathrm{~g}$ body weight. Rats were divided into two groups of equal mean body weights.

\section{EXPERIMENTAL PROTOCOL}

Ethanol $(0.4 \mathrm{~g} / \mathrm{ml}$ water $)$ was injected ip into treated rats at a dose of $75 \mathrm{mmol} / \mathrm{kg}$ body weight, without restraint, between $0900 \mathrm{~h}-1100 \mathrm{~h}$. Control rats were injected ip with isovolumetric $0 \cdot 15 \mathrm{~mol} / 1 \mathrm{NaCl}$. Rats were replaced in their cages with free access to food and water and after, 140 minutes, were injected with $\mathrm{L}\left[4^{3} \mathrm{H}\right]$-phenylalanine to measure rates of protein synthesis by the technique of Garlick et al. ${ }^{9}$

Rats were briefly wrapped in J-cloths (disposable towels) and $\mathrm{L}\left[4^{3} \mathrm{H}\right]$-phenylalanine $(0.3 \mathrm{Ci} / \mathrm{mol} ; 150$ $\mathrm{mmol} / \mathrm{l} ; 150 \mu \mathrm{mol} / 100 \mathrm{~g}$ body weight) was injected via a tail vein. Immediately after injection, rats were unwrapped and placed back in their cages. Ten minutes after injection of isotope, rats were decapitated. Blood was collected in cold heparinised tubes for plasma extraction and the entire small intestine was rapidly dissected out and immediately placed in an ice/water mixture. The small intestine was then flushed with ice cold $0.15 \mathrm{M} \mathrm{NaCl}$ and the first $15 \mathrm{~cm}$ of the small intestine $(600-1000 \mathrm{mg})$ frozen in liquid nitrogen. Samples were stored at $-70^{\circ} \mathrm{C}$ until analysis.

The small intestine was homogenised in $10 \mathrm{ml}$ water $\left(4^{\circ} \mathrm{C}\right)$ in an ultrasonic tissue homogeniser (Polytron, The Northern Media Supply Co Ltd, Hull), with $3 \times 10$ seconds bursts on full setting. An amount equivalent to $200-400 \mathrm{mg}$ tissue was then rapidly precipitated with $0.2 \mathrm{~mol} / \mathrm{l}$ perchloric acid, for measurement of whole tissue protein and RNA (described below). The remaining homogenate was separated into cytoplasmic and contractile proteins on the basis of differential solubilities in potassium buffers, as described by Smith and Sugden. ${ }^{10}$ As many separation techniques have been used for tissue proteins, we have defined the cytoplasmic fraction as those proteins soluble in low ionic buffer, which are not precipitated at $33000 \mathrm{~g}$ centrifugation under the conditions described by Smith and Sugden. ${ }^{10}$ The contractile fraction was defined as that fraction soluble in high ionic buffer, which was not precipitated at $33000 \mathrm{~g}$ centrifugation. ${ }^{10}$

Extracted proteins were then acid precipitated and treated in exactly the same way as mixed tissue protein fractions. All subsequent steps were carried out at $4^{\circ} \mathrm{C}$. After centrifugation $(2000 \mathrm{~g}, 10$ minutes $)$ the supernatants of mixed tissue fraction were neutralised with saturated tripotassium citrate for determination of $S_{i}$, the specific radioactivity of free phenylalanine in tissue homogenate. ${ }^{9}$ Mixed, cytoplasmic and contractile protein pellets were then washed eight times with $12-14 \mathrm{ml} 0 \cdot 2 \mathrm{~mol} / \mathrm{l}$ perchloric acid.

After heating in $3 \mathrm{ml} 6 \mathrm{~mol} / 1$ hydrochloric acid $\left(36 \mathrm{~h}, 105^{\circ} \mathrm{C}\right)$, the hydrolysates were dried in vacuo and the residue was suspended in citrate buffer $(1.5$ $\mathrm{mol} / \mathrm{l} ; \mathrm{pH} \mathrm{6.3)}$ for determination of $S_{B}$, the specific radioactivity of phenylalanine in tissue protein. ${ }^{9}$ The specific radioactivity of free phenylalanine in plasma, $\mathrm{S}_{\mathrm{p}}$, was determined in the supernatant after precipitation of the proteins with $0.2 \mathrm{~mol} / \mathrm{l}$ perchloric acid and subsequent neutralisation -with saturated tripotassium citrate.

Phenylalanine specific radioactivities in tissue, plasma and protein were converted to 2phenylethylamine and assayed by fluorimetry, and radioactivity by scintillation spectrophotometry. ${ }^{9}$

Fractional rates of protein synthesis (defined as the percentage of tissue protein renewed each day by synthesis) were calculated from:

$$
\mathrm{k}_{\mathrm{s}}=\frac{\mathrm{S}_{\mathrm{B}} \times 100}{\overline{\mathrm{S}_{\mathrm{i}} \times \mathrm{t}}}(\% / \text { day })
$$

where $\overline{S i}$ is the mean specific radioactivity of the free phenylalanine in acid supernatants of tissue homogenates during synthesis measurement. The above calculation assumes that proteins are labelled from free phenylalanine in the intracellular compartment. As there is no direct experimental evidence to support this, the $\mathrm{k}_{\mathrm{s}}$ was also calculated assuming that the free label in extracellular pools was incorporated into protein - that is, by substituting $\overline{S i}$ with $\overline{S p}$ in the above formula.

RNA and protein in the mixed fraction was measured by precipitating the protein in $0.2 \mathrm{~mol} / \mathrm{l}$ $\mathrm{HClO}_{4}$. After washing twice in $12-14 \mathrm{ml}$ of $0 \cdot 2$ $\mathrm{mol} / / \mathrm{HClO}_{4}$, the pellet was suspended in $10 \mathrm{ml} 0 \cdot 3$ $\mathrm{mol} / \mathrm{l} \mathrm{NaOH}$ and incubated for one hour at $37^{\circ} \mathrm{C}$. An aliquot was taken for protein estimation. ${ }^{9}$ The remaining solubilised protein was reprecipitated with $2 \mathrm{ml} 2 \mathrm{~mol} / 1 \mathrm{HClO}_{4}$ and RNA measured in the supernatant as previously described. ${ }^{911}$

\section{STATISTICAL ANALYSIS}

All data are shown as mean (SE) of six observations in each group. Differences between control and treated data were assessed by Student's $t$ test, with significance at the level $p \leqslant 0 \cdot 05$. For the ratios (Table 2) $\log$ transformation of the data was carried out before statistical treatment.

\section{Results}

In response to acute ethanol dosage, there was a significant reduction in the concentration of contrac- 
Table 1 Effect of acute ethanol dosage on phenylalanine specific radioactivities and synthesis rates of mixed proteins of the small intestine

\begin{tabular}{|c|c|c|c|}
\hline & Control & Ethanol & $p$ \\
\hline$\overline{\overline{S i}}(\mathrm{dpm} / \mathrm{nmol})$ & $551(10)$ & $491(25)$ & $<0.05$ \\
\hline$\overline{\mathrm{Sp}}(\mathrm{dpm} / \mathrm{nmol})$ & $678(4)$ & $703(6)$ & $<0.05$ \\
\hline $\mathrm{S}_{\mathrm{B}}(\mathrm{dpm} / \mathrm{nmol})$ & $5 \cdot 46(0 \cdot 18)$ & $4 \cdot 11(0 \cdot 35)$ & $<0.01$ \\
\hline $\mathrm{k}_{\mathrm{s}}$, calculated from $\mathrm{S}_{\mathrm{i}}(\% /$ day $)$ & $119(3)$ & $101(8)$ & $\leqslant 0.05$ \\
\hline $\mathrm{k}_{\mathrm{s}}$, calculated from $\mathrm{S}_{\mathrm{p}}(\% /$ day $)$ & $97(3)$ & $71(6)$ & $<0.005$ \\
\hline RNA/protein (mg/g) & $34 \cdot 4(0 \cdot 4)$ & $34 \cdot 0(1 \cdot 0)$ & $>0.05$ \\
\hline $\begin{array}{l}\text { RNA efficiency calculated from } \\
\mathrm{S}_{\mathrm{i}} \text { (mg protein/day/mg RNA) }\end{array}$ & $34 \cdot 7(1 \cdot 0)$ & $29 \cdot 9(2 \cdot 6)$ & $>0 \cdot 05$ \\
\hline $\begin{array}{r}\text { RNA efficiency calculated from } \\
S_{p} \text { (mg protein/day/mg RNA) }\end{array}$ & $28 \cdot 2(1 \cdot 0)$ & $21 \cdot 0(2 \cdot 1)$ & $<0.025$ \\
\hline
\end{tabular}

Rats were injected intraperitoneally with either saline (controls) or ethanol ( $75 \mathrm{mmol} / \mathrm{kg}$ body weight). At the end of $2.5 \mathrm{~h}$ rats were injected with $\mathrm{L}-\left[4^{-}{ }^{3} \mathrm{H}\right]$-phenylalanine to measure rates of protein synthesis and the rats were killed and the small intestine rapidly removed for measurement of phenylalanine specific radioactivities, RNA and protein, in tissue homogenate. $\bar{S}_{i}$ and $\bar{S}_{p}$ refers to mean free phenylalanine specific radioactivities in tissue homogenate and plasma, respectively, while $S_{B}$ refers to the specific radioactivities of phenylalanine in hydrolysed protein. All data are expressed as mean (SE) of six observations in each group. Differences between control and treated groups were assessed by Student's $t$ test.

tile proteins, from $19(1) \mathrm{mg} / \mathrm{g}$ wet weight in controls (mean (SE) of six observations) to $15(1) \mathrm{mg} / \mathrm{g}$ wet weight in ethanol treated rats $(n=6, p<0 \cdot 001)$. There was also a smaller decline in the concentration of cytoplasmic proteins, from $58(3) \mathrm{mg} / \mathrm{g}$ wet weight in controls to $50(4) \mathrm{mg} / \mathrm{g}$ wet weight in ethanol-treated rats. This was not, however, statistically significant $(p>0.05)$. The amount of protein in the mixed protein fraction was also analysed, which also showed no change - that is, 128 (3) and $126(4) \mathrm{mg} / \mathrm{g}$ wet weight in control and ethanol-dosed rats, respectively $(\mathrm{p}>0.05)$. We did not analyse the fraction containing connective tissue and other proteins responsible for structural rigidity of the gut - that is, collagen and other unextractable proteins. Presumably, the difference between the sum of the cytoplasmic plus contractile and the mixed homogenate of the small intestine comprises this fraction. Consideration should also be given to the possibility that there may have been losses of protein during processing. Control and treated samples were analysed simultaneously, however, and this factor will equally apply to both groups. ${ }^{10}$

The data in Table 1 show that in the mixed protein $\overline{S i}$ and $S_{B}$ were decreased by ethanol treatment, while $\overline{\mathrm{Sp}}$ was increased. When expressed as fractional rates of protein synthesis, there was a $15 \%$ decline in the value of $k_{s}$, calculated from the assumption that amino acids were incorporated into tissue protein through the intracellular pool. Corresponding values
Table 2 Effect of acute ethanol dosage on phenylalanine specific radioactivities and synthesis rates of cytoplasmic and contractile proteins of the small intestine

\begin{tabular}{|c|c|c|c|}
\hline & Control & Ethanol & $p$ \\
\hline \multicolumn{4}{|c|}{ Specific radioactivities $\left(S_{B}, d p m / n m o l\right)$} \\
\hline Cytoplasmic & $5 \cdot 93(0 \cdot 15)$ & $3.94(0.46)$ & $<0.005$ \\
\hline Contractile & $4 \cdot 52(0 \cdot 27)$ & $2 \cdot 41(0.31)$ & $<0.001$ \\
\hline \multicolumn{4}{|c|}{ Synthesis rates (\%/day) } \\
\hline \multicolumn{4}{|c|}{ Calculated from $\mathrm{S}_{\mathrm{i}}$} \\
\hline Cytoplasmic & $129(1)$ & $97(10)$ & $\begin{array}{l}<0.025 \\
<0.001\end{array}$ \\
\hline Contractile & $99(6)$ & $58(6)$ & $<0.001$ \\
\hline \multicolumn{4}{|c|}{ Calculated from $\mathrm{S}_{\mathrm{p}}$} \\
\hline Contractile & $80(6)$ & $41(5)$ & $<0.001$ \\
\hline \multicolumn{4}{|c|}{$\begin{array}{l}\text { Ratios of synthesis rates } \\
\text { Mixed }\end{array}$} \\
\hline Cytoplasmic & $0.92(0.02)$ & $1.07(0.09)$ & $>0 \cdot 05$ \\
\hline \multicolumn{4}{|l|}{ Mixed } \\
\hline Contractile & $1 \cdot 22(0 \cdot 06)$ & $1 \cdot 77(0 \cdot 11)$ & $<0.005$ \\
\hline \multicolumn{4}{|l|}{ Cytoplasmic } \\
\hline Contractile & $1 \cdot 33(0.07)$ & $1 \cdot 68(0 \cdot 14)$ & $<0.05$ \\
\hline
\end{tabular}

Small intestine was separated into cytoplasmic and contractile proteins by differential salt extraction. Values for the specific radioactivities of mixed tissue protein $\left(S_{B}\right)$ were obtained from Table 1. All data are expressed as mean (SE) of six observations in each group. Differences between control and treated groups was assessed by Student's $t$ test. To compare differences between the ratios, log transformation of the data were carried out before statistical analysis.

for $\mathrm{k}_{\mathrm{s}}$ calculated from $\overline{\mathrm{Sp}}$ showed a $27 \%$ decline. Similar differences were obtained when synthesis was calculated as the amount of protein synthesised per day per unit RNA - that is, a $14 \%$ and $25 \%$ decline in RNA efficiency, when calculated from $\overline{\mathrm{Si}}$ and $\overline{\mathrm{Sp}}$, respectively.

Table 2 shows the synthesis data pertaining to the cytoplasmic (33000 g supernatant) and contractile proteins. Specific radioactivities of cytoplasmic and contractile protein $\left[{ }^{3} \mathrm{H}\right]$-phenylalanine were reduced by ethanol treatment, by $33 \%$ and $47 \%$, respectively. Fractional synthesis rates of both protein fractions were also reduced by ethanol. Values for the cytoplasmic proteins fell by between $25 \%$ (calculated from $\overline{\mathrm{Si}}$ ) and $35 \%$ (calculated from $\overline{\mathrm{Sp}}$ ). Corresponding decreases for the contractile proteins were between $41 \%$ and $48 \%$, respectively. Inspection of the ratios of synthesis rates showed that the different protein fractions displayed different sensitivities to ethanol. There were statistically significant increases in the ratio: mixed protein synthesis/ contractile protein synthesis rates (44\% increase) and cytoplasmic protein synthesis/contractile protein synthesis rates ( $26 \%$ increase). 


\section{Discussion}

The data demonstrated that in control animals the fractional rate of protein synthesis in the gut was approximately $100-120 \%$ /day. This was similar to values obtained by McNurlan et $a l^{11}$ for similar sized fed rats, using leucine as the precursor amino acid. Our data showed, however, that the small intestine was relatively insensitive to the acute effects of ethanol, when examined as a mixed tissue. When the small intestine was separated into different compartments, cytoplasmic and contractile proteins had different synthesis rates. Fractional rates of protein synthesis in the cytoplasmic fraction was approximately $30 \%$ higher than the contractile protein fraction. This is the first occasion in which accurate and reliable rates of protein synthesis in the smooth muscle of the small intestine have been reported for a comparison between a normal and a pathophysiological state. The isolation of contractile proteins per se contrasted with the approach of McNurlan and Garlick who separated the serosa and mucosa by scraping the lumen with a glass slide. By this method fractional rates of protein synthesis in the mucosa was two to three times the value for serosa. "12 The serosa also consists of a large proportion of non-muscle cells containing soluble proteins. Furthermore, the mucosal layer also contains contractile proteins - that is, actin filaments in microvilli. ${ }^{13}$ Thus the physical separation of cells of the small intestine does not really provide information on smooth muscle protein perse.

The small intestine expressed differential sensitivity in response to ethanol. The fraction derived from smooth muscle protein was more responsive to the inhibitory effects of ethanol on protein synthesis. This was particularly evident as the ratios of mixed/ contractile and cytoplasmic/contractile synthesis rates in individual animals increased. As the small intestine has a high rate of protein synthesis - that is, on average the entire protein mass being replaced every 24 hours, it was possible to calculate the theoretical reduction in the concentration of contractile protein from ethanol treated rats. In the absence of any change in protein degradation $(89 \%$ /day as measured from the difference between synthesis that is, $99 \%$ /day, and growth, ie $10 \%$ /day, a difference of approximately $1 \mathrm{mg} / \mathrm{g}$ wet weight should have been produced by ethanol treatment. In this study the measured concentration of contractile proteins fell from a mean of 19 to $15 \mathrm{mg} / \mathrm{g}$ in ethanol dosed rats. This difference was larger than the predicted value but confirms that the deposition of contractile proteins was reduced by ethanol. It was also possible that the smooth muscle protein from ethanol treated rats had different solubility characteristics from the control animals. Alternatively the rate of protein breakdown increased in response to ethanol treatment, as implied from the concept of protein turnover. ${ }^{14}$ This process, however, is very difficult to measure in vivo in acute studies, as discussed by Waterlow et $_{\text {al. }}{ }^{14}$

Various studies have shown that ethanol does not overtly affect type I (slow twitch, aerobic) fibres, though type II (fast twitch, anaerobic) muscle fibres of skeletal muscle are selectively damaged. ${ }^{15}$ This would indicate that ethanol may have minimal effects on protein synthesis in the continually active muscle of the gut. Consideration should also be given to physiological and biochemical differences between skeletal and smooth muscle protein. For example, the gut depends largely on glycolysis for energy requirements and smooth muscle has a higher tropomyosin content in relation to other contractile protein. ${ }^{16}$ The gut also has a much lower blood flow rate than skeletal muscle. ${ }^{17}$

It was difficult to propose a mechanism responsible for the reduction in smooth muscle protein synthesis in response to ethanol, as so little is known about the regulation of protein synthesis in the gut. Ethanol treatment results in a variety of biochemical and hormonal responses, any one of which may alter synthesis. ${ }^{18}$ For example, acute exposur ? to ethanol decreases ATP of small intestine segm ents. ${ }^{19}$ The main point, however, is that our studies have important implications for explaining the functional disturbances in gut motility often seen in alcoholic patients.

The secretarial skills of Janet Gilbert are gratefully acknowledged. We also wish to thank Philip Gibbs and Paul Edwards for assistance in dissections.

\section{References}

1 Levi AJ, Chalmers DM. Recognition of alcoholic liver disease in a district general hospital. Gut 1978; 19: 521-5.

2 Lindenbaum $\mathbf{J}$, Lieber CS. Effect of chronic ethanol administration on intestinal absorption in man in the absence of nutritional deficiency. Ann NY Acad Sci 1975; 252: 238-44.

3 Roggin GM, Iber FL, Kater RMH, Tobon F. Malabsorption in the chronic alcoholic. Johns Hopkins Med J 1969; 125: 321-30.

4 Baroana E, Pirola RC, Lieber CS. Small intestinal damage and changes in cell population produced by ethanol ingestion in the rat. Gastroenterology 1974; 66: 226-34.

5 Bjarnason I, Smethurst P, Levi AJ, Peters TJ. Intestinal permeability to ${ }^{51} \mathrm{Cr}$-EDTA in rats with experimental induced enteropathy. Gut 1985; 26: 579-85.

6 Robles EA, Mezey E, Halsted CH, Schuster MM. 
Effect of ethanol on motility of the small intestine. Johns Hopkins Med J 1974; 135: 17-24.

7 Angel F, Sava P, Crenner F, Lambert A, Grenier JF. Modifications de la mortricite intestinale aprés injection intraveineuse d'alcool. C R Soc Biol (Paris) 1980; 174: 192-8.

8 Berenson MM, Avner DL. Alcohol inhibition of rectosigmoid motility in humans. Digestion $1981 ; 22$ : 210-5.

9 Garlick PJ, McNurlan MA, Preedy VR. A rapid and convenient technique for measuring the rate of protein synthesis in tissues by injection of $\left[{ }^{3} \mathrm{H}\right]$-phenylalanine. Biochem J 1980; 192: 719-23.

10 Smith DM, Sugden PH. Rates of synthesis of actomyosin in atria and ventricles of the perfused working heart. Cardiovasc Res 1985; 19: 552-8.

11 McNurlan MA, Tomkins AM. Garlick PJ. The effect of starvation on the rate of protein synthesis in rat liver and small intestine. Biochem J 1979; 178: 373-9.

12 McNurlan MA, Garlick PJ. Protein synthesis in liver and small intestine in protein deprivation and diabetes. Am J Physiol 1981; 241: E238-45.

13 Fawcett DW. In: A textbook of histology. Philadelphia: WB Saunders, 1986: 641-78.
14 Waterlow JC, Garlick PJ, Millward DJ. Protein turnover in mammalian tissues and in the whole-body. Amsterdam: North-Holland, 1978.

15 Martin FC, Ward K, Slavin G, Levi J, Peters TJ. Alcoholic skeletal myopathy, a clinical and pathological study. $Q J$ Med 1985; 55: 233-51.

16 Needham DM, Shoenberg CF. Proteins of the contractile mechanism in vertebrate smooth muscle. In: Code CF, ed. Handbook of physiology. Vol 4. Washington: American Physiological Society, 1968.

17 Preedy VR, Venkatesan S, Peters TJ, Nott D, Yates J, Jenkins S. Effect of chronic ethanol administration on musculo-skeletal blood flow in the rat. Biochem Soc Trans 1988; 16: 576-7.

18 In: Maling HM, Highman B, Hunter JM, Butler WM, Williams MA. Blood alcohol levels, triglyceride, fatty livers and pathological changes in rats after single doses of alcohol. Maickel R-P, ed. Biochemical factors in alcoholism. New York: Pergamon Press, 1967: 185-99.

19 Krasner N, Carmichael HA, Russell RI, Thompson GG, Cochran KM. Alcohol and absorption from the small intestine. 2. Effect of ethanol on ATP and ATPase activities in guinea-pig jejunum. Gut 1976; 17: 249-51. 